\title{
Impact Assessment of Water Translocation from the Tucutunemo River to Camatagua Reservoir (Aragua State, Venezuela)
}

Matos, M.L. ${ }^{1}$, Guajardo, N. ${ }^{1}$

'Universidad Central de Venezuela - UCV y Universidad de los Andes - ULA, Caracas, Venezuela

Corresponding autor: lenymatos@gmail.com, guajardo.nadia@gmail.com

\section{Abstract}

In order to control the increase of water level of Lake of Valencia, during 2009 began the translocation of water from the Taiguaiguay reservoir, through the Tuc utunemo and Guárico rivers, to Camatagua reservoir, which is used as the main source of drinking water for the city of Caracas; this water translocation stopped in J anuary 2015. C onsidering that water of Taigua igua y reservo ir is fed with treated wastewater from Ta iguaiguay treatment plant, which is rich in nutrients, mainly $\mathrm{P}$ and $\mathrm{N}$, the objec tive of this study was to evaluate the impact of water transfer from Taigua iguay reservoir on water quality and quantity of Camatagua reservoir. We a nalyzed the data from 37 sa mples made from 2012 to 2016, near the water intake, in which in situ mea surements and samples were taken for physic ochemic al and biologic al a nalysis (Secchi disk transpa rency, turbidity, a mmonia, phosphates, total dissolved phosphorus, total phosphorus and phytoplankton abundance). Decrease in translocation flow from 2013, until its final elimination in 2015, caused a marked decrease in the water level of $C$ amatagua resenoir. Water transparency and turbidity were affected by the entry of water from the Taiguaiguay reservoir. Also, ammonia and total phosphorus 
concentrations showed an inc rea se from 2012 to 2016, as a consequence of the high content of nutrients reaching to Camatagua reservoir from Taiguaiguay reservoir, as well as the decomposition of the organic matter. Nutrient input stimula ted the increa se of phytoplankton density with dominance of the species Cylind rospermopsis racib orskii, Oscilla toria planctonica, Leptolyng bya limnetica, Mic rocystis a eruginosa and Synechocystis aquatilis for the whole study period.

Keywords: water translocation, ca mata gua reservoir, water quality, eutrophication.

\section{Introduction}

In order to control the water level increase in Lake Valencia, during 2009 the excess of water of Taiguaiguay reservoir was tra sloc ated to the Tuc utunemo River, which joins downstream to the Guá ric o River, the main affluent of the Camatagua resenoir (G ONZÁLEZ et al., 2015). The water from Tuc utunemo River is ric $h$ in nutrients (mostly $\mathrm{N}$ and $\mathrm{P}$ ), which come from the Taiguaigua y treated wastewater treatment plant.

Camatagua is the main drinking water reservoir for the City of Caracas and other adjacent populations (ca. 6 million of inhabitants). The impact of this translocation affected the water quality supplied for human consume, increased the eutrophication process of reservoir

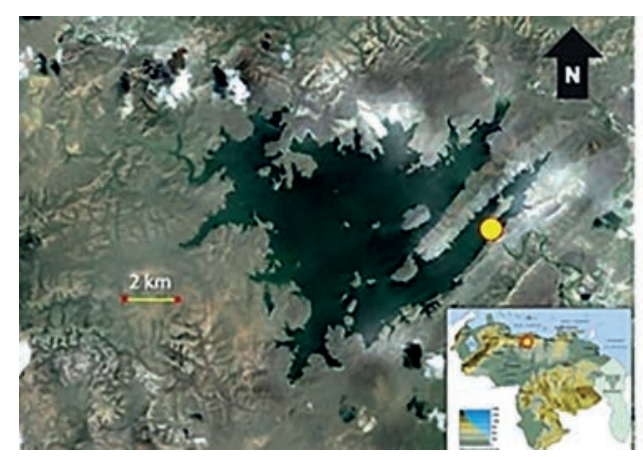

and, by this rea son, it finished in J a nuary 2015.

Camatagua resenoir was classified as eutrophic, according to the criteria of Salas and Martinó (1991) for warm tropical lakes, based on the concentration of total phosphorus (G ONZÁLEZ, 2017).

\section{Objective}

Evaluate the impact of water translocation from Ta iguaiguay reservo ir on the water quality and qua ntity of Camatagua reservoir.

\section{Study Area}

Camatagua reservoir is located in the Central region of Venezuela (Figure 1).

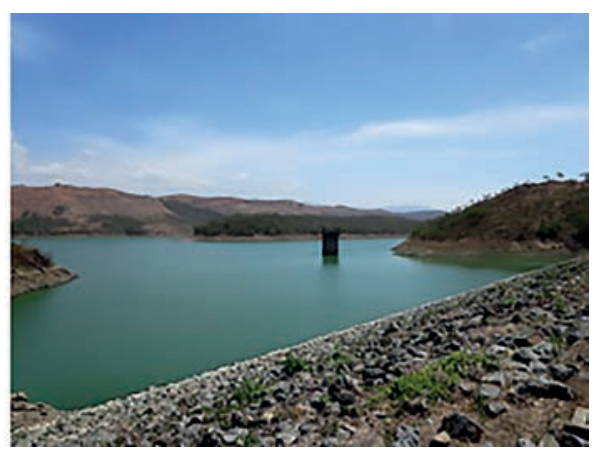

Figure 1 - Relative location of Camatagua reservoir and the sampling site ( ) near the uptake tower. 
Main morphometric

characteristics

of the Camatagua

reservoir

The ma in morphometric characteristics of Camatagua reservoir a re (CASTILLO et al., 1973):

- Geographic location: 950’ N $67^{\circ} 00^{\prime} \mathrm{W}$

- Surface: $59,000,000 \mathrm{~m}^{2}$

- Volume: 1,250,000,000 $\mathrm{m}^{3}$

- Altitude: 302 m.a.s.l.

- Mean depth: $21 \mathrm{~m}$

- Discharge: $19 \mathrm{~m}^{3} / \mathrm{s}$

\section{Methods}

Da ta were analyzed from a total of 37 quarterly sa mples from 2012 to 2016, near the uptake tower in Camatagua reservoir. Samples were taken at the three levels: surface, intermediate and bottom, using a van Dom bottle for physic oc hemic al ana lysis and for phytoplankton in the euphotic layer. In the field, water transparency was measured (Sec chi disk $20 \mathrm{~cm}$ in diameter).

Once in the laboratory, the following variables were a nalyzed:

- Turbidity: Nephelometer HACH.

- Ammonia, phosphates, total dissolved phosphorus and total phosphorus: Standard Methods (APHA, 1992).
- Biological va riables: Phytopla nkton

Samples were fixed with lugol solution. Phytoplankton species were identified after sedimentation in Uthermöhl chambers, observation underan inverted mic roscope and the help of taxonomic al keys for the elaboration of the species inventory. Algal density was determined by counting of c ells in Sedgewick-Rafter and Uthermöhl chambers, with the help of an optical mic rosc ope (APHA, 1992).

Results of all determined variables are shown based on the annual a verage values of the water column. Flow of water transferred from the Ta igua igua y reservoir to the Tuc utunemo River c orresponds to the annual average value.

\section{Results and discussion}

- Translocation diagram from Taiguaiguay reservoir to Camatagua reservoir: During 2009, water translocation from the Taiguaiguay reservoir to the Tuc utunemo River and after to the Camatagua reservoir was made, with an initial flow of $3000 \mathrm{l} / \mathrm{s}$. Figures 2 and 3 show the diagram of water translocation from Taiguaiguay reservoir to Camatagua reservoir. Figure 2 clearly shows clearly the high input of $\mathrm{N}$ and $\mathrm{P}$ to the Guárico River from the Tuc utunemo River. 


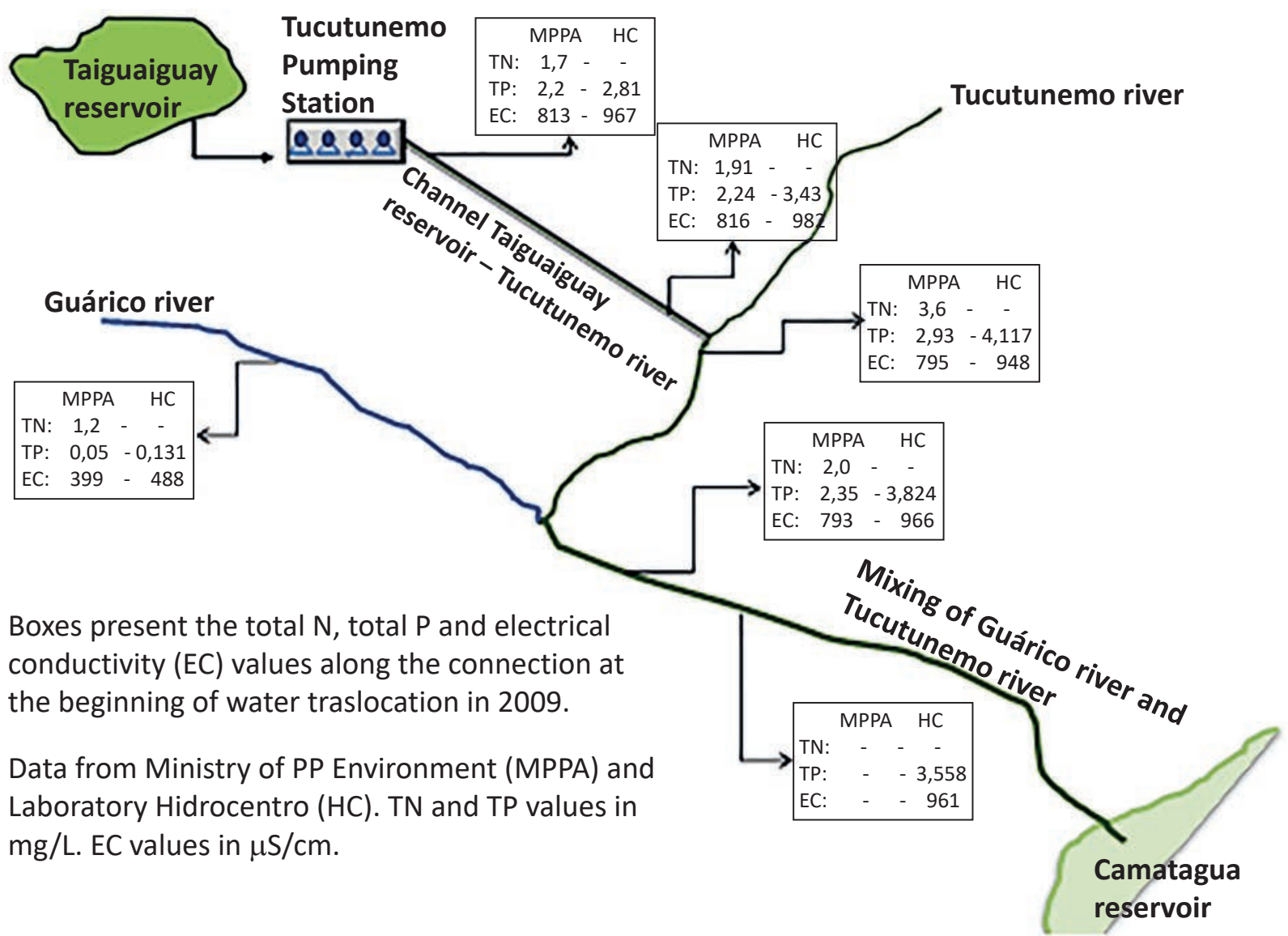

Figure 2 - Diagram of water translocation from Taiguaiguay reservoir to Camatagua reservoir and values of $\mathrm{P}, \mathrm{N}$ and $\mathrm{CE}$ in 2009.

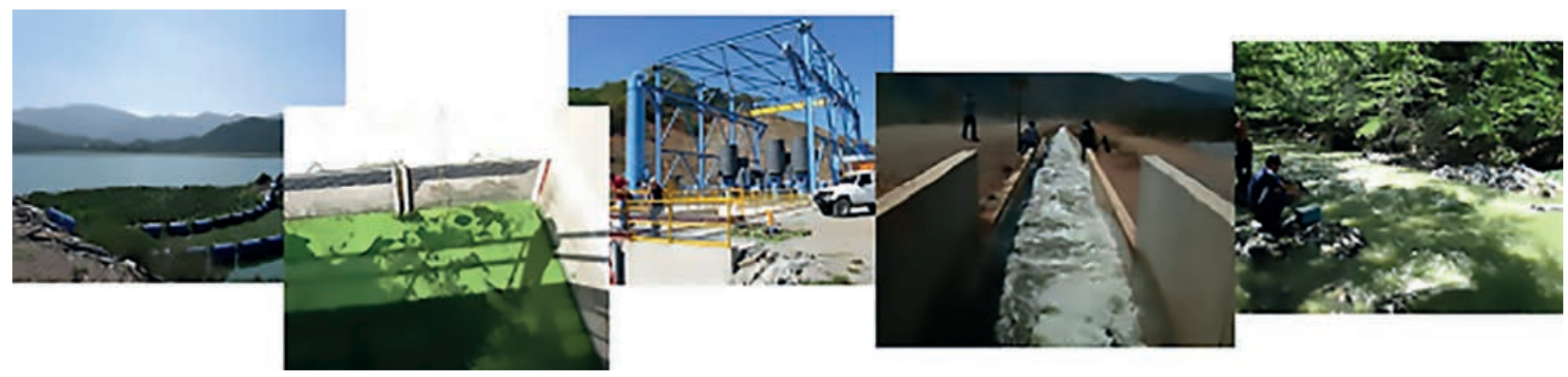

Figure 3 - Flow of translocation from the Taiguaiguay reservoir to the Tucutunemo River. It can be noted the development of a thick layer of phytoplankton in the pit of the pumping station. 
- Translocation and water level in Camatagua resenoir: Water translocation made to control water level of Lake of Valencia, contributed to maintain the nomal level of water in Camatagua reservoir. The decrease in translocation flow from 2013, until its final elimination in 2015, caused a marked decrease in the water level in Camatagua reservoir (Figure 4).

- Transparency and turbidity: Transparency and turbidity (Figure 5) were affected by the entry of water from the Taiguaiguay reservoir. The impact on water qua lity was still present, even after the stop of translocation. As in 2013 , a decrease in water transparency was observed, probably due to the increase in turbidity and the high abundance of phytoplankton, which give the water a turbid greenish color, limiting penetration of light only to a few centimeters from the surface (euphotic layer with no more than $2 \mathrm{~m}$ of extension).

- Ammonia concentration: Ammonia concentration (Figure 6) also showed an increase from 2012 to 2016, as a consequence of the high content of nutrients rea ching the Camatagua reservoir from the Ta iguaiguay reservoir, as well as from the increased organic matter decomposition.

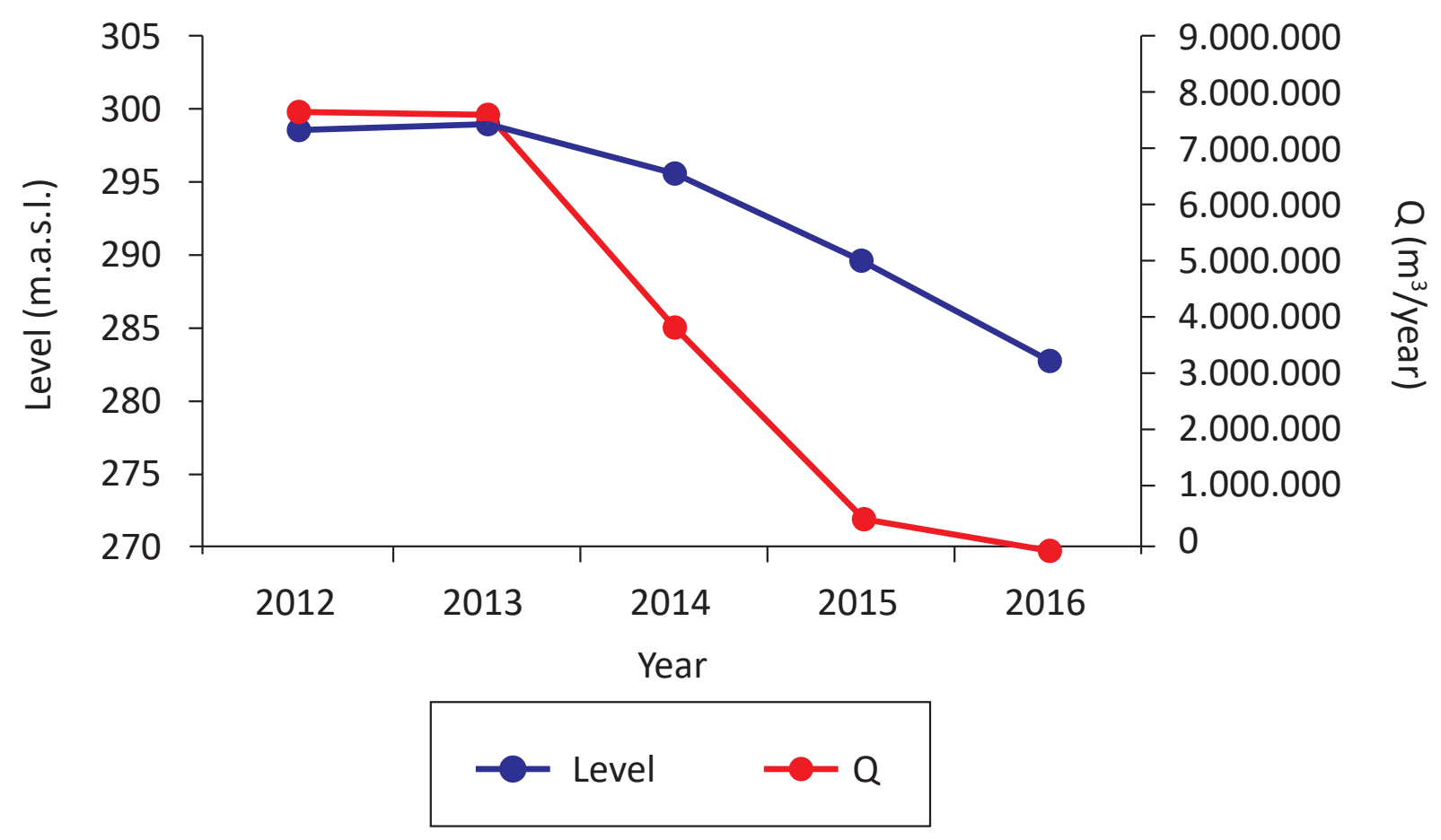

Figure 4 - Relationship between water translocation (Q) and water level in Camatagua reservoir. 

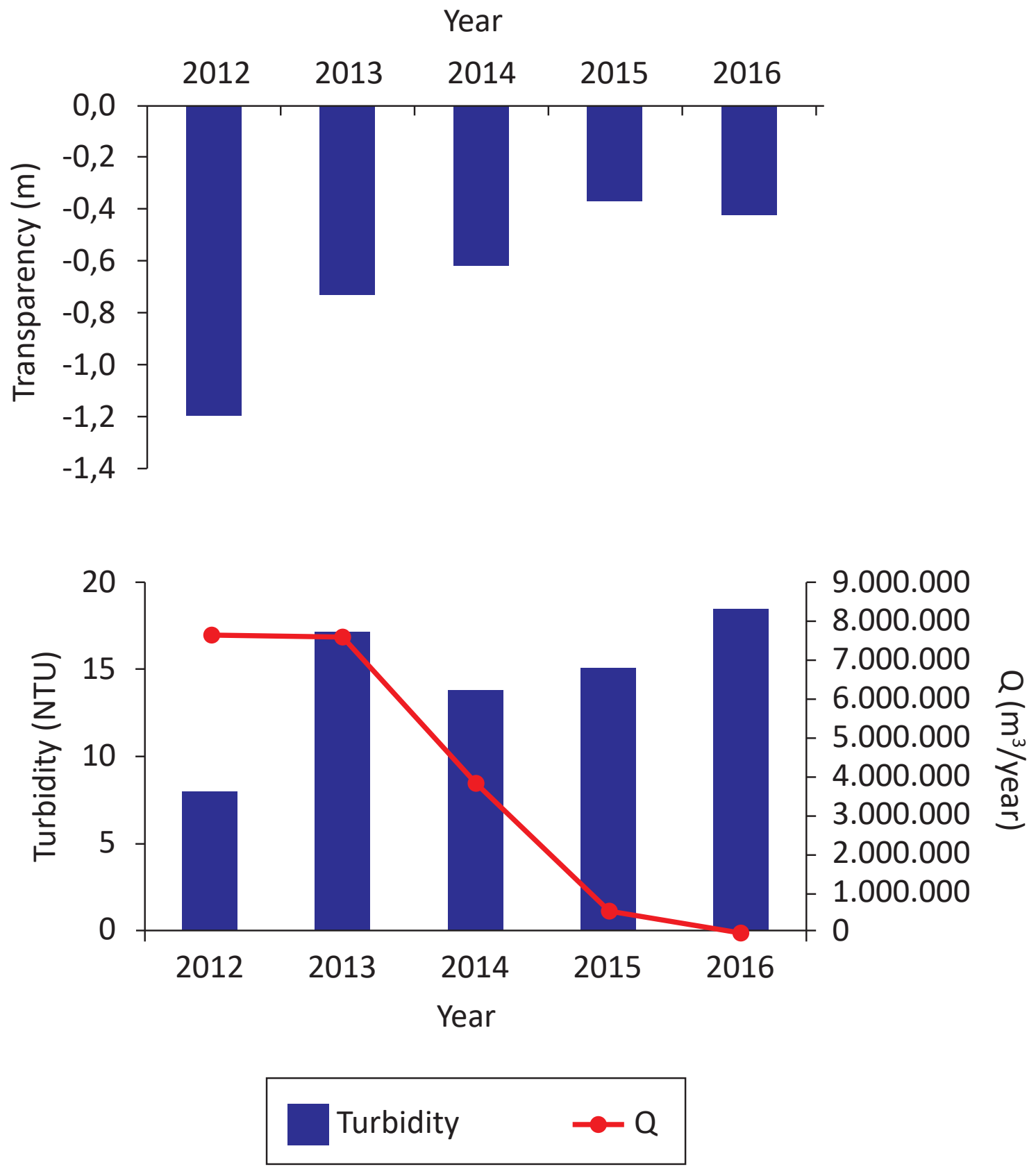

Figure 5 - Relationship between water translocation (Q), transparency and turbidity in Camatagua reservoir. 


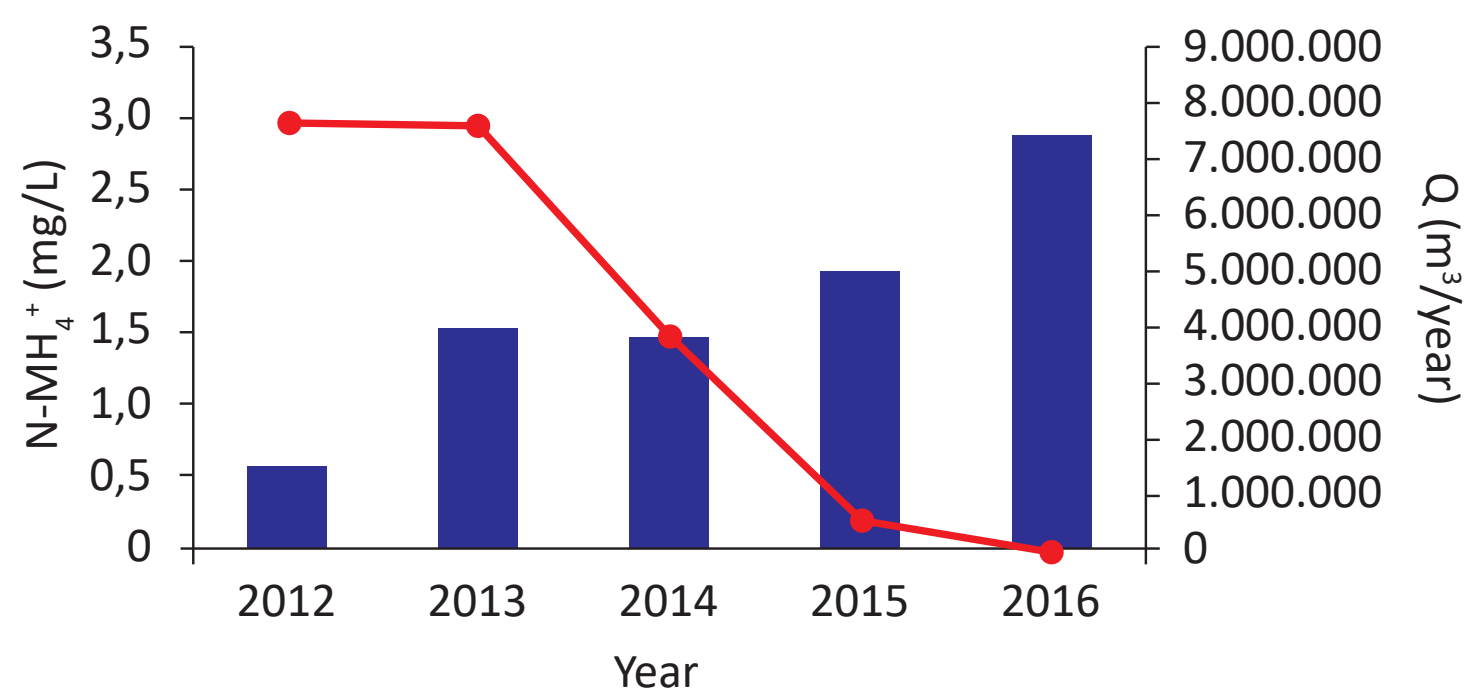

Ammonia $\rightarrow$ Q

Figure 6 - Relationship between water translocation (Q) and ammonia in Camatagua reservoir.

- Orthophosphate, total dissolved phosphorus and total phosphorus concentrations: Ortho phosphate, total dissolved phosphorus and total phosphorus concentration (Figure 7) also showed the same trend of ammonia. According to Salas, Martinó (1991) criteria, this water body was classified as eutrophic. The total-P increased from $40 \mu \mathrm{g} / \mathrm{L}$ in 1992 , to more than $80 \mu \mathrm{g} / \mathrm{L}$ in the euphotic layer (GONZÁLEZ, 2017).
- Phytoplankton: Nutrient input stimulated the increase of phytoplankton density (Figure 8 ) and this community had a change in its composition. Cyanobacteria now accounted up to $90 \%$ of the relative proportion. Cylind rospermopsis raciborskii, Oscillatoria planctonica, Leptolyngbya limnetica, Microcystis aeruginosa and Synechocystis aquatilis were the dominant species during the whole study period. 

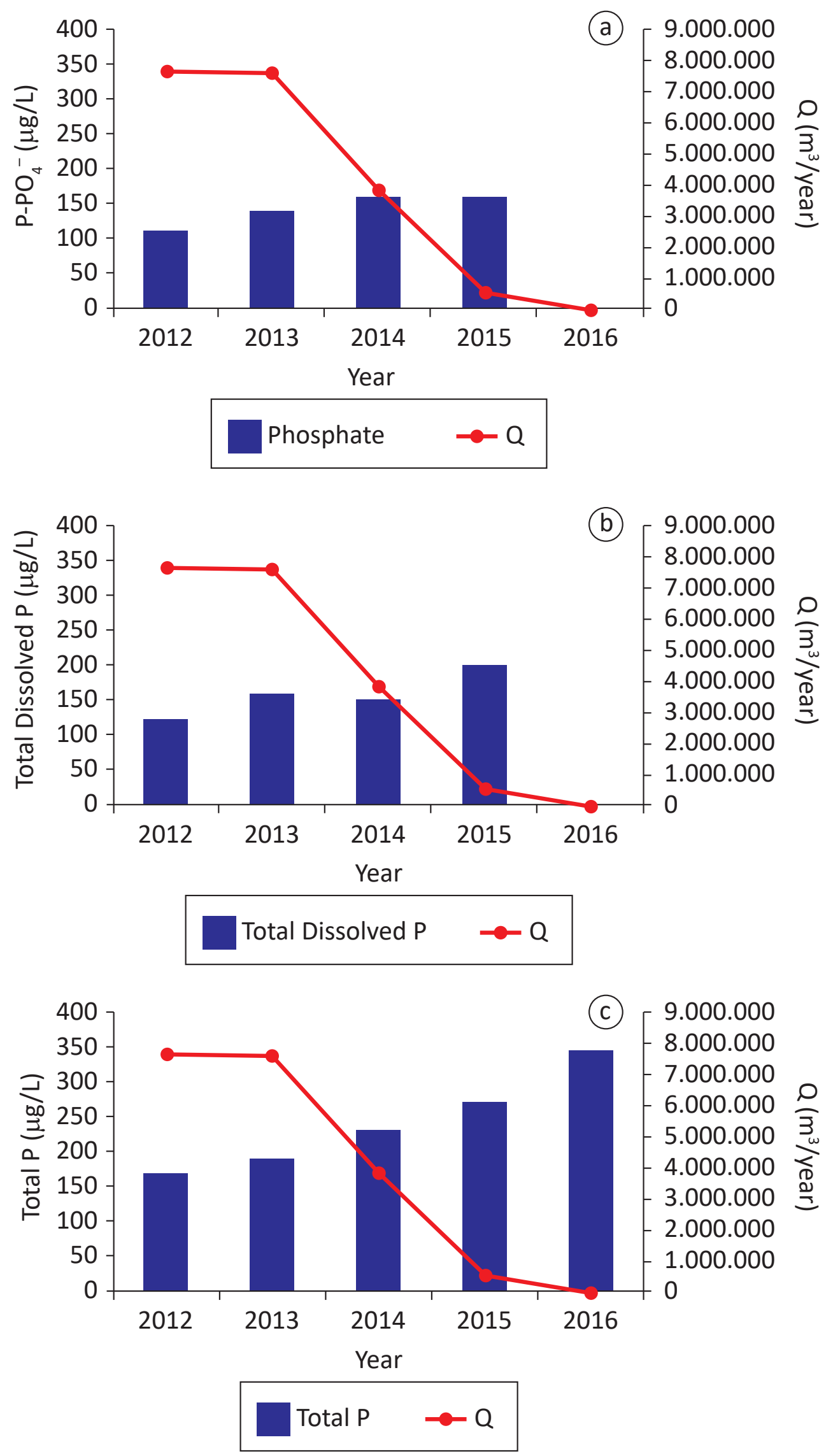

Figure 7 - Relationship between water translocation (Q) and orthophosphate (a), total dissolved phosphorus (b) and total phosphorus (c) in Camatagua reservoir. 


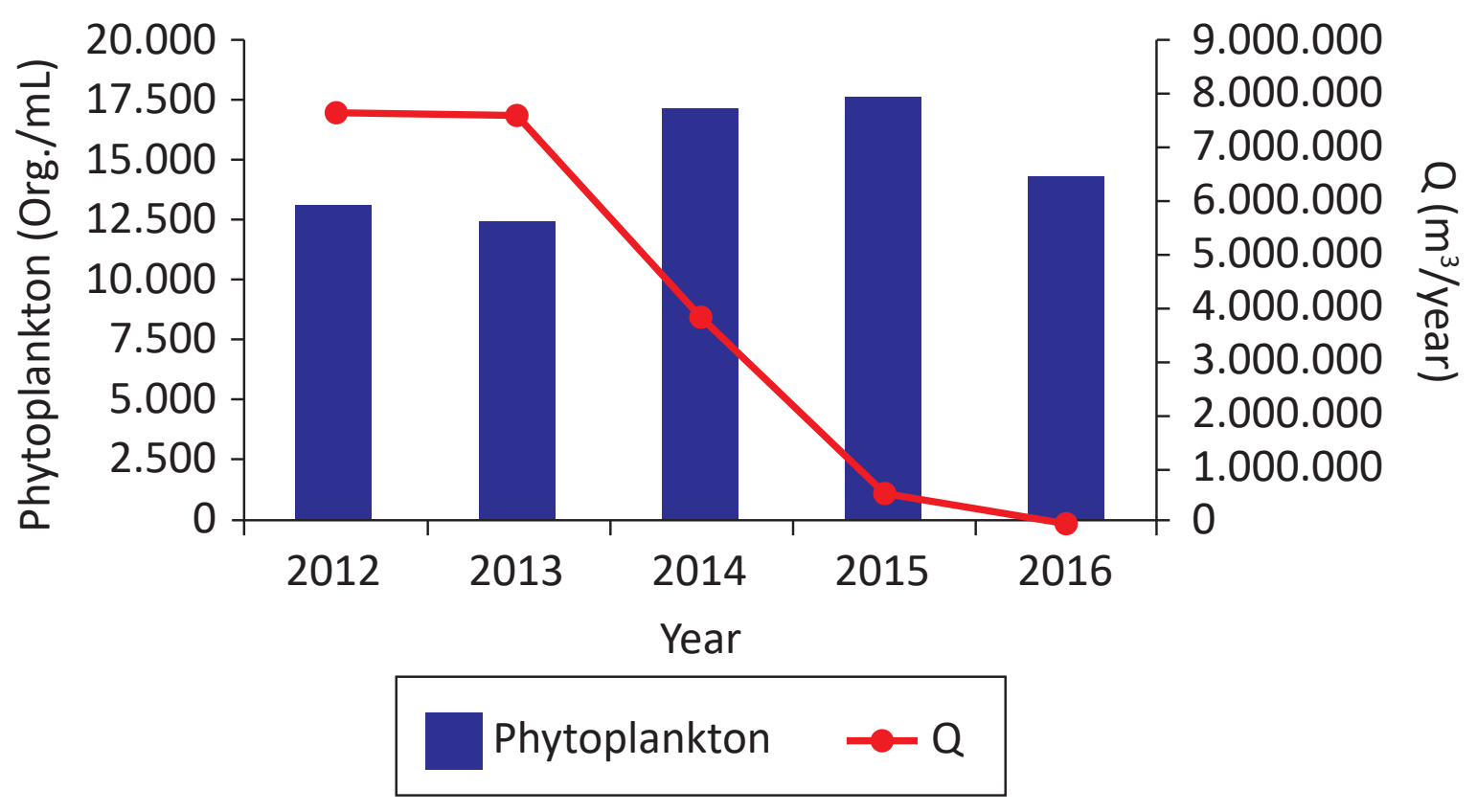

Figure 8 - Relationship between water translocation (Q) and phytoplankton abundance in Camatagua reservoir.

\section{Conclusions}

Water transloc a tion from Ta igua iguay resenoir brought a relative benefit of maintaining the water volume in Camatagua reservoir at normal levels, but affecting its wa ter qua lity.

Despite the reduction of the transloc ation since 2013 until its total elimination in J a nuary 2015, a mmonia, orthophosphate, total dissolved phosphorus and total phosphorus concentrations, continue to increase in Camatagua resenoir, probably due to the decrease of watervolume in Camatagua reservoir that also contributed to the increase of nutrient concentration.

An increase in phytoplankton abundance was also noted, mainly Cya nobacteria species, as a result of the nutrient input from the Taguaiguay reservoir.

Trophic state of Camatagua reservo ir changed from oligo-mesotrophic in 1992, to eutrophic after the water translocation.

\section{Acknowledgements}

Authors wish to thank the hydrological compa nies HIDRO CENTRO, HIDRO C APITAL a nd HIDROVEN, for fina ncial a nd logistic al support. We also thank E. González, who helped in the review of this a rticle. M. L. Matos thanks the São Paulo Research Foundation (FAPESP) and International Institute of Ecology (IIE) for the travel grant to assist to the International Tra ining Course of the São Paulo Advanced School on Integrated Water Resources Management, held in São Carlos, Sã o Paulo Sta te, Brazil, from November $2^{\text {nd }}$ to $17^{\text {th }}, 2017$. 


\section{References}

APHA, 1992. Standard methods for the examination of water and wastewater. 18th. edition. APHA, AWWA, WEF. Washington.

CASTILLO, C.E., GÓMEZ, J. and MONTES, C., 1973.

El Agua. Serie Embalses de Venezuela, vol.1, no. especial. Caracas.

GONZÁLEZ, E.J., 2017. Evaluación limnológica del embalse Camatagua (Edos. Aragua y Guárico). Informe Final del Proyecto PEII 20110001391. FONACIT. Caracas, $37 \mathrm{p}$.
GONZÁLEZ, E.J., MATOS, M.L., BUROZ, E., OCHOAITURBE, J., MACHADO-ALLISON, A., MARTÍNEZ, R. and MONTERO, R., 2015. Urban Water. Venezuela. In: ROLDÁN, G., TORREGROSA, M.L., VAMMEN, K., GONZÁLEZ, E.J., CAMPUZANO, C. and DE LA CRUZ, A. (Eds.). Urban Water Challenges in the Americas. Perspectives from the Academies of Sciences. Inter-American Network of Academies of Sciences (IANAS) - Programa de Aguas, con apoyo de IHPUNESCO. ISBN 978-607-8379-12-5. México: 556-601.

SALAS, H. and MARTINÓ, P., 1991. A simplified phosphorus trophic model state for warm-water tropical lakes. Wat. Res., vol. 25, pp. 341-350. 